Letters to the Editor

\section{Temperature Activity of Serum Cholinesterases}

In a recent paper (King and Morgan, 1970) the properties of the very rare homozygote for the fluoride-resistant serum cholinesterase could only be postulated. Our subsequent study of two cases of this phenotype $E_{1}{ }^{p} E_{1}{ }^{p}$ is insufficient to be conclusive but results indicate that predictions regarding the kinetic behaviour of this variant were substantially correct.

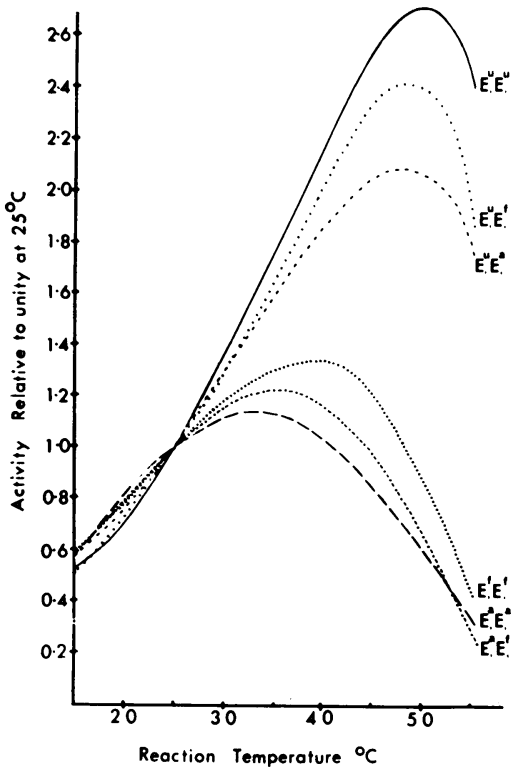

With benzoylcholine substrate at 50 $\boldsymbol{\mu}$ moles/l maximum activity is obtained at a reaction temperature of $40^{\circ} \mathrm{C}$, the $Q_{10}\left(25^{\circ}-35^{\circ} \mathrm{C}\right)$ is $1 \cdot 30$, and the correction factors from $25^{\circ} \mathrm{C}$ and $30^{\circ} \mathrm{C}$ to $37^{\circ} \mathrm{C}$ are respectively 1.33 and $1 \cdot 14$. This represents a divergence of nearly $20 \%$ from the atypical homozygote, $\mathrm{E}_{1}{ }^{\mathrm{a}} \mathrm{E}_{1} \mathrm{a}$, for which temperature correction factors were given and, as predicted, would necessitate a separate table of factors for this isoenzyme. While only an indication of these factors can be obtained from two specimens, the matter may take some time to resolve fully, as Lehmann and Liddell (1969) have calculated that the genotype $E_{1}{ }^{1} E_{1}{ }^{l}$ occurred once in 300,000 of the population and $\mathrm{E}_{1}{ }^{\mathrm{P}} \mathrm{E}_{1}{ }^{8}$ once in 200,000 .

J. KING AND H. G. MORGAN Department of Biochemistry, Royal Infirmary, Glasgow, C.4.

\section{References}

King, J., and Morgan, H. G. (1970). The temperature activity relationships of serum cholinesterases. J. clin. Path., 23, 730-732.

Lehmann, H., and Liddell, J. (1969). Human cholinesterase (pseudocholinesterase): genetic variants and their recogitinon. Brit. J. Anaesth., 41, 235-255.

\section{A Rapid Tube Test for Sickling}

We were interested in the report by Canning and Huntsman (1970) on the assessment of Sickledex.

We have developed an essentially similar system using known reagents of negligible cost, with minor modifications which make the test more reliable and eliminate the few false positives which occur with the Sickledex preparation. The most frequent need for rapid identification of sickle cell haemoglobin is among possible heterzygotes who although not anaemic, are under risk under conditions of anoxia which may occur, for example, in pneumonia or inadvertently during anaesthesia. The test described is undoubtedly much quicker and more reliable than the microscopic observation of sickling under reduced oxygen tension.

REAGENTS

A stock phosphate buffer is prepared containing $26.0 \%$ dry dipotassium hydrogen phosphate $\left(\mathrm{K}_{2} \mathrm{HPO}_{4}\right)$ and $10.7 \%$ of dry potassium dihydrogen phosphate $\left(\mathrm{KH}_{2} \mathrm{PO}_{4}\right)$. The salts should be dried at $120^{\circ} \mathrm{C}$ for one to two hours before use.

The working reagent is prepared by adding to each $100 \mathrm{ml}$ of stock buffer $5 \mathrm{~g}$ sodium dithionite $\left(\mathrm{Na}_{2} \mathrm{~S}_{2} \mathrm{O}_{4}\right)$ and $0.2 \mathrm{~g}$ of white saponin (British Drug Houses). The final $p \mathrm{H}$ is $6 \cdot 8$. The reagent should be kept in a tightly stoppered container and stored at $4^{\circ} \mathrm{C}$. It should be prepared from stock buffer each week. Loss of reducing activity is easily detected during the test by the negative control which fails to produce the purple tint of reduced haemoglobin; the brighter red of oxyhaemoglobin is easily differentiated. Furthermore, after centrifugation with a known positive $\mathrm{Hb}-\mathrm{S}$ control, instead of a clear straw-coloured solution, some degree of haemolysis is observed (see below).

\section{PROCEDURE}

Blood samples taken into sequestrene or heparin or oxalate mixtures are suitable for testing. Approximately $0.02 \mathrm{ml}$ whole blood is added to $2 \mathrm{ml}$ of reagent in a 3 in. $\times \frac{1}{2}$ in. test tube. If the colour pro- duced by this $1 / 100$ dilution differs markedl from that produced by a sample of normab haemoglobin content, a larger amount of blood should be used to make the colours more nearly approximate. A known $\mathrm{Hb}-\bar{E}$ positive blood sample and a normal bloog sample should be similarly treated. The tubes are left at room temperature fof five minutes and examined for turbidity The tubes are then centrifuged at about $3,000 \mathrm{rpm}$ for three to five minutes. I $\overrightarrow{\mathrm{f}^{\prime}}$ severe anaemia, ie, with $\mathrm{Hb}$ concentratioळ less than $7 \mathrm{~g}$ per $100 \mathrm{ml}$, it is advisable tक concentrate the red cell suspension b. removing an adequate amount of supen natant plasma before testing.

The result is read by two criteriabo 1 Red cells containing $\mathrm{Hb}-\mathrm{S}$ in th队 reduced state are resistant to saponir haemolysis and the blood suspension in tho reagent remains turbid. A negative result, that is, a clear but slightly haemolyse opalescent solution, is seen within fiv minutes. Reliance on turbidity alone may occasionally give false positive readings where plasma protein concentrations arel high as in myeloma (also noted by Canning and Huntsman), or in the presence of severe anaemia where the amount of plasma relative to red cells high, when turbidity due to precipitatiog of plasma proteins may occur.

2 Separation of the unhaemolysed $\mathrm{Hb}-\stackrel{\$}{-}$ containing cells by centrifugation. Afte centrifuging the unhaemolysed $\mathrm{Hb}-\mathrm{S}$ coß taining red cells rise to the surface leavin a virtually clear straw-coloured solution. The occasional false positives as judged by turbidity alone are eliminated in thịs way. Ten minutes is required to comple the test. Prolonged standing will produe the same effects as centrifugation.

We have tested numerous samples of various types of heterozygote $\mathrm{Hb}-\Phi$ samples and many homozygote $\mathrm{Hb}-\overline{3}$ samples and found no false positive false negative results by this methot; when checked against electrophoresis.

$$
\begin{array}{r}
\text { M. D. MUSTAE } \\
\text { Khartout } \\
\text { J. FIELDING } \\
\text { Haematology Department } \\
\text { St Mary's Hospital (Harrow Road } \\
\text { Lond }
\end{array}
$$

Reference

Canning, D. F., and Huntsman, R. G. (1970). assessment of Sickledex as an alternative $R$ the sickling test. J. clin. Path., 23, 736. 